\title{
MICROBIAL-INDUCED CALCITE PRECIPITATION: A MILESTONE TOWARDS SOIL IMPROVEMENT
}

\author{
ABDULAZIZ ALIYU DARDAU ${ }^{1,2}$, MUSKHAZLI MUSTAFA $^{1 *}$ and NOR AZWADY ABD AZIZ ${ }^{1}$ \\ ${ }^{1}$ Department of Biology, Faculty of Sciences, Universiti Putra Malaysia, Serdang 43400, \\ Selangor Darul Ehsan, Malaysia \\ ${ }^{2}$ Department of Microbiology, Federal University of Lafia, Lafia, Akunza 950101, \\ Nasarawa State, Nigeria \\ *E-mail: muskhazli@upm.edu.my
}

Accepted 18 February 2021, Published online 5 April 2021

\begin{abstract}
Microbial-induced calcite precipitation (MICP) is a natural process that offered various applications in the engineering field materials and construction industry. It has recently emerged as an innovative, eco-friendly, and economically engineered process. One of the successful MICP methods of improving the engineering properties of soils is ureolysis. The ureolysis drove the process of precipitate calcite which binds soil particles within the soil matrix thus enhance soil characteristics such as stiffness, permeability, hydraulic conductivity, shear strength, and compressive strength. This paper aimed at reviewing the concept of utilizing calcium carbonate $\left(\mathrm{CaCO}_{3}\right)$ precipitation by ureolytic bacteria towards the improvement of soil and sand engineering properties for various geotechnical applications. The potential applications of this technology in soil erosion, stability, and reinforcement were discussed. Detail overviews of the temperature, $\mathrm{pH}$, bacteria cell concentration, nutrients, types of bacteria, and concentration of reactants that affect the efficiency of the process are also reviewed. This review demonstrated the potential of the MICP technology from the laboratory to a field-scale or commercial applications.
\end{abstract}

Key words: Biomineralization, Calcium carbonate, calcite, urease enzyme, ureolysis, ureolytic bacteria

\section{INTRODUCTION}

In this contemporary world, fast population growth and urbanization have made lands available for raising infrastructures relatively scarce and people are left to make use of problematic loose soils to develop earth structures (Chang et al., 2016; Hiranya et al., 2018). These weak and problematic soils affect the safety and stability of structures constructed on them, due to over shear stress or limitation of shear strength applied during loading onto the soil. This condition consequently fails the built structures. It is almost impossible or expensive to replace problematic soils such as soft marine clay that is commonly found at riverbanks and coastal areas as they can extend to a great depth (Saad et al., 2018). This situation improves soil mechanical properties crucial. An investigation carried out in 2008 reported that over six billion US dollars were spent annually to finance over forty thousand soil improvement

* To whom correspondence should be addressed. projects worldwide (Kalantary \& Kahani, 2015). Although, for the past few years, several methods and materials were developed to improve the engineering characteristics of soils. However, they varied in terms of environmental impact, cost, penetration depth, and treatment uniformity which portrays their merits and demerits (Khan et al., 2016; Duo et al., 2018). For example, the major material often use for chemical grouting is cement, but the production of cement is energy consuming and ecologically unfriendly, as it contributes to world carbon dioxide $\left(\mathrm{CO}_{2}\right)$ emissions by $7 \%$ (Hiranya et al., 2018). This draws the interest of researchers towards the idea of simulating nature for the improvement of loose soils.

Microbially induced calcite precipitation (MICP) or bio-cementation is a bio-mediated, environmentally conscious soil improvement technique that can improve the engineering properties of granular soils. It refers to the process of precipitation of calcium carbonates $\left(\mathrm{CaCO}_{3}\right)$ in a microenvironment from a supersaturated solution as a result of microbial 
and biochemical activities (Omoregie et al., 2016; Omoregie et al., 2018). The MICP is a biomineralization process that involves the reaction between carbonate ions $\left(\mathrm{CO}_{3}{ }^{2-}\right)$ produce by microbes with available calcium ions $\left(\mathrm{Ca}^{2+}\right)$ within the microenvironment by which results in the precipitation of $\mathrm{CaCO}_{3}$ mineral (Omoregie et al., 2018). The precipitated $\mathrm{CaCO}_{3}$ fills the pore spaces within the soil matrix leading to improvement of the engineering properties of the soil. MICP is highly desirable as it is contamination-free of natural microbial activity. The process offers unique functions and features that have favored highperformance applications and innovations in the engineering field materials and construction industry (Park et al., 2010; Montaño et al., 2017). Among the various branch of biomineralization, MICP is the most widely studied and employed in many applications such as soil improvement (DeJong et al., 2010; Khamehchiyan et al., 2015), manufacturing of bio-bricks (Lambert \& Randall, 2019), bio concrete (Cheng et al., 2014; Mondal \& Ghosh, 2019), compressive strength improvement in a mortar (Park et al., 2010), biocementation (Zamani \& Montoya, 2019), wastewater treatment (Hammes et al., 2003), construction materials (Muynck et al., 2010), microbially enhanced oil recovery (Nemati et al., 2005), healing of cracks in concrete structures (Ruan et al., 2019; Jongvivatsakul et al., 2019) and dust control (Meyer et al., 2011). This current review aimed to discuss the biomineralization using calcium carbonate precipitation by ureolytic bacteria, factors affecting its efficiency, and application of MICP towards soil and sand improvement.

\section{BIOMINERALIZATION}

Biominerals are abundant in nature existing in the form of anthills, mollusks shells, beautiful corals, caves, teeth, rocks, and bones (Dhami et al., 2013). Recently, researchers across the world are focusing on these biominerals to harness their technical applications in various fields. So far, about sixty biominerals such as silica, calcium phosphate, barite, magnetite, and fluorite have been described and documented (Nudelman, 2015; Chaparro-Acuña et al., 2017). Among these, calcium carbonates and calcium phosphates are the main families that are particularly abundant in nature (Azaïs et al., 2019).

Biomineralization is the process by which microbial activity results in the chemical alteration of an environment leading to the precipitation of minerals. This process provides control over the composition, size, morphology, and structure of biominerals, given rising to complex materials with well-defined structures and distinct properties that are of great dissimilarity with geological materials and surpass synthetic analogues (Krajewska, 2018). It is a natural phenomenon occurring in virtually all living organisms ranging from prokaryotes to higher vertebrates (Chen et al., 2019). There are broadly three type of mechanisms involved in the synthesis of these biominerals;

(i) Biologically Controlled Mineralisation (BCM) involves the synthesis of minerals inclusive of their growth, morphology, composition, and location that occurs only under certain conditions at a precise location within or on the cell. Mineral structures that are well defined for example shells, bones, fish otoliths, and teeth are formed through this process (Arias et al., 2017; Chen et al., 2019; Seifan \& Berenjian, 2019).

(ii) Biologically Influenced Mineralisation (BIM) refers to the passive precipitation of minerals accompanied by cell surface organic matter such as extracellular polymeric substances that are commonly associated with biofilms (Phillips et al., 2013a; Arias et al., 2017).

(iii) Biologically Induced Mineralization (BIM) is the process by which the biological activity of an organism results in modification of the environment chemically leading to supersaturation and mineral precipitation. The features of the minerals induced by this process include wide particle size distribution and amorphous or poorly crystalline calcium carbonate formation (Chaparro-Acuña et al., 2017; Seifan \& Berenjian, 2019).

Bacteria involved in biomineralization can promote an alteration in the geological properties of soil or any component of the earth, thereby improving the soil quality by enhancing soil stiffness via the production of calcite precipitate. This is important towards soil improvement particularly in areas and towns with windy and desert-like environments such as the Gulf region due to higher temperatures and calcium content in the soil (Bibi et al., 2018). Among the various applications of ureaseproducing bacteria, soil improvement is highly recommended (Burbank et al., 2012).

\section{SOIL AND SAND IMPROVEMENT VIA MICP}

Soil improvement is a universal term for any chemical, biological, physical, and combined technique of altering the natural soil to meet up with engineering purposes. The first introduction of microbial application to biogeochemical engineering was in the year 1992 (Gunjo \& Youn, 2016). The process 
involves the production of sediments that can bind grains together due to chemical reactions catalyzed by microbes, which result in an alteration within the soil matrix that stiffens and strengthens the soil (Burbank et al., 2011; Gunjo \& Youn, 2016). As such it is seen as an eco-friendly and novel ground improvement technique (Hiranya et al., 2018). It is a naturally occurring process as the microorganisms are available in nature. A large number of species ranging from autotrophic to heterotrophic microbes are involved in this process of calcium carbonate precipitation in different environments such as caves, soils, oceans, and saline/soda lakes (Sarayu et al., 2014; Seifan \& Berenjian, 2019). Although the largest global $\mathrm{CaCO}_{3}$ precipitation occurs due to biotic processes that take place in the oceans, the biosynthesis of microbial carbonate precipitation may be achieved through various mechanisms as listed in Table 1.
Noteworthy, microbial precipitation of $\mathrm{CaCO}_{3}$ through hydrolysis of urea (neurolysis) is more favorably utilized for various technical applications due to energy efficiency due to its capability of inducing a high amount of $\mathrm{CaCO}_{3}$ in a short duration of time (Krajewska, 2018; Mukherjee et al., 2019). The process involves urea hydrolysis that results in $\mathrm{CaCO}_{3}$ precipitation through biochemical reactions governed by the production of urease enzyme by ureolytic bacteria. It is an ideal methodology in civil engineering and geotechnology because it occurs within a diverse group of microorganisms as a common microbial process (Montaño et al., 2017; Fujita et al., 2017). Ureolysis is distinguished from other metabolic pathways by its high amount of $\mathrm{CaCO}_{3}$ yield and is used for MICP soil treatments, which is carried out with the aid of urease-producing bacteria (Krajewska, 2018; Seifan \& Berenjian, 2019). There two common mechanisms in microbial

Table 1. An application and limitation of various MICP metabolic pathway

\begin{tabular}{|c|c|c|c|c|}
\hline $\begin{array}{l}\text { Metabolic } \\
\text { Pathway }\end{array}$ & Bacteria & $\begin{array}{l}\text { Precipitated } \\
\text { crystal }\end{array}$ & Application & Limitation \\
\hline \multirow[t]{3}{*}{ Ureolysis } & $\begin{array}{l}\text { Bacillus } \\
\text { sphaericus }\end{array}$ & Calcite & $\begin{array}{l}\text { - Dispersive soils stabilization } \\
\text { (Moravej et al., 2018) }\end{array}$ & $\begin{array}{l}\text { - Release of toxic ammonia gas } \\
\text { and nitric acid production } \\
\text { (Ganendra et al., 2014) }\end{array}$ \\
\hline & $\begin{array}{l}\text { Sporosarcina } \\
\text { pasteurii }\end{array}$ & $\begin{array}{l}\text { Calcium } \\
\text { carbonate }\end{array}$ & $\begin{array}{l}\text { - Silty sands improvement } \\
\text { (Zamani \& Montoya, 2019) }\end{array}$ & \\
\hline & $\begin{array}{l}\text { Proteus } \\
\text { vulgaris }\end{array}$ & $\begin{array}{l}\text { Calcium } \\
\text { carbonate }\end{array}$ & $\begin{array}{l}\text { - Microbially enhanced oil } \\
\text { recovery (Nemati et al., 2005) }\end{array}$ & \\
\hline Photosynthesis & Chorella sp. & Calcite & $\begin{array}{l}\text { - Biological } \mathrm{CO}_{2} \text { sequestration } \\
\text { (Ramanan et al., 2010) }\end{array}$ & $\begin{array}{l}\text { - In the dark, respiration result } \\
\text { to decalcification } \\
\text { (Bissett et al., 2008) }\end{array}$ \\
\hline $\begin{array}{l}\text { Sulfate } \\
\text { reduction }\end{array}$ & $\begin{array}{l}\text { Desulfovibrio } \\
\text { sp. }\end{array}$ & $\begin{array}{l}\text { Calcium } \\
\text { carbonate }\end{array}$ & $\begin{array}{l}\text { - Lithifying microbial mats } \\
\text { (Braissant et al., 2007) }\end{array}$ & $\begin{array}{l}\text { - Ineffective in hypersaline and } \\
\text { alkaline waters (Meister, 2013) }\end{array}$ \\
\hline Ammonification & $\begin{array}{l}\text { Myxococcus } \\
\text { xanthus }\end{array}$ & $\begin{array}{l}\text { Calcite } \\
\text { Vaterite }\end{array}$ & $\begin{array}{l}\text { - Conservation of ornamental } \\
\text { stone (Rodriguez-Navarro } \\
\text { et al., 2003) }\end{array}$ & $\begin{array}{l}\text { - Production of ammonia gas } \\
\text { (Li et al., 2015) }\end{array}$ \\
\hline Denitrification & $\begin{array}{l}\text { Pseudomonas } \\
\text { aeruginosa }\end{array}$ & $\begin{array}{l}\text { Calcite } \\
\text { Aragonite }\end{array}$ & $\begin{array}{l}\text { Papermill wastewater } \\
\text { treatment } \\
\text { (Ersan et al., 2015) }\end{array}$ & $\begin{array}{l}\text { - Occurrence of poisonous } \\
\text { inhibitive intermediates (nitrous } \\
\text { oxide and nitrite) (van Paassen } \\
\text { et al., 2009) }\end{array}$ \\
\hline $\begin{array}{l}\text { Anaerobic } \\
\text { sulfide }\end{array}$ & $\begin{array}{l}\text { Sulfate- } \\
\text { reducing } \\
\text { bacteria }\end{array}$ & Dolomite & $\begin{array}{l}\text { - Carbonate sedimentation } \\
\text { oxidation (Warthmann } \\
\text { et al., 2015) }\end{array}$ & $\begin{array}{l}\text { - Ineffective in hypersaline and } \\
\text { alkaline waters (Meister, 2013) }\end{array}$ \\
\hline $\begin{array}{l}\text { Methano- } \\
\text { synthesis }\end{array}$ & $\begin{array}{l}\text { Methylocystis } \\
\text { parvus }\end{array}$ & $\begin{array}{l}\text { Calcite } \\
\text { Vaterite }\end{array}$ & $\begin{array}{l}\text { - Calcium carbonate deposition } \\
\text { (Ganendra et al., 2014) }\end{array}$ & $\begin{array}{l}\text { Depressed water potential } \\
\text { lowers uptake of methane per } \\
\text { unit of biomass (Schnell \& } \\
\text { King, 1996) }\end{array}$ \\
\hline $\begin{array}{l}\text { Utilization of } \\
\text { organic acids } \\
\text { to } \mathrm{CaCO}_{3}\end{array}$ & $\begin{array}{l}\text { Bacillus } \\
\text { subtilis }\end{array}$ & $\begin{array}{l}\text { Calcium } \\
\text { carbonate }\end{array}$ & $\begin{array}{l}\text { Crack healing in concrete } \\
\text { (Khaliq \& Ehsan, 2016) }\end{array}$ & $\begin{array}{l}\text { - Adsorption affinity of organic } \\
\text { acids decrease the precipitation } \\
\text { rate of minerals (Kawano \& } \\
\text { Tokonami, 2014) }\end{array}$ \\
\hline
\end{tabular}


precipitation of $\mathrm{CaCO}_{3}$ as shown in Figure 1. The bacteria catalyze the intracellular hydrolysis of urea $\left(\mathrm{CO}\left(\mathrm{NH}_{2}\right)_{2}\right)$ by the urease enzyme to ammonia $\left(\mathrm{NH}_{3}\right)$ and carbamate $\left(\mathrm{NH}_{2} \mathrm{COOH}\right)$. This carbamate decomposes simultaneously to form carbon dioxide $\left(\mathrm{CO}_{2}\right)$ and ammonia $\left(\mathrm{NH}_{3}\right)$. These products are further transformed into carbonate $\left(\mathrm{HCO}_{3}^{-}\right)$, ammonium $\left(\mathrm{NH}_{4}{ }^{+}\right)$, and hydroxyl $\left(\mathrm{OH}^{-}\right)$ions. This process increases the $\mathrm{pH}$ value due to the production of $\mathrm{NH}_{4}{ }^{+}$. The carbonate ions react with calcium ions $\left(\mathrm{Ca}^{2+}\right)$ available in the surrounding environment under saturation conditions, which favors the precipitation of $\mathrm{CaCO}_{3}$ as described in Figure 1A (Kumari \& Xiang, 2017; Mahawish et al., 2018). Further, $\mathrm{CaCO}_{3}$ can be precipitated on the bacterial cell surface with a net negative charge and attract calcium ions rapidly and tightly to its cell wall. These calcium ions react with dissolved carbonate ions to precipitate $\mathrm{CaCO}_{3}$ as shown in Figure 1B (Renner \& Weibel, 2011; Helmi et al., 2016).

Microbial precipitation of calcium carbonate has proven its potential as a microbial geotechnologybased method that is adapted for soil improvement. It is applied for various soil improvement projects such as controlling erosion in rivers and coastal areas, enhancing the stability of non-piled and piled foundations, treating pavement surface, decreasing dust levels on exposed surfaces by binding together the dust particles, reinforcing soil for the enhancement of underground constructions (Wath \& Pusadkar, 2016). There were several reports (Burbank et al., 2011; Jiang et al., 2016; Fujita et al., 2017; Krajewska 2018) that had drawn our attention to the possibility of stimulating in situ soil urease positive bacteria in natural soils. With the presence of urease-positive bacteria and the availability of $\mathrm{Ca}^{2+}$, the precipitation of $\mathrm{CaCO}_{3}$ may be produced in adequate quantities to change the engineering properties of the soils. The coral sand solidification test has been carried out using this methodology with Pararhodobacter sp. as the microbial strain that shown the specimen has solidified with unconfined compressive strength (UCS) with a value reading up to $12 \mathrm{MPa}$ after a curing time of 14 days (Khan et al., 2016). This confirmed that MICP is an effective technique for enhancing sandy soil characteristics.

However, the major issue affecting this technique is bioclogging, which occurs due to uneven distribution and uniformity of precipitated $\mathrm{CaCO}_{3}$ in tested sand columns (Rowshanbakht et al., 2016; Omoregie et al., 2018). This resulted in the retention of the cementation solution and bacterial culture at the treatment injection point. Thus, it may affect the overall stiffness and shear strength of the treated samples. Factors that influencing the transport and attachment of bacteria to soil grains are including, flow rate, cell surface properties, Vander Waals forces, ionic strength of carrier solution, and

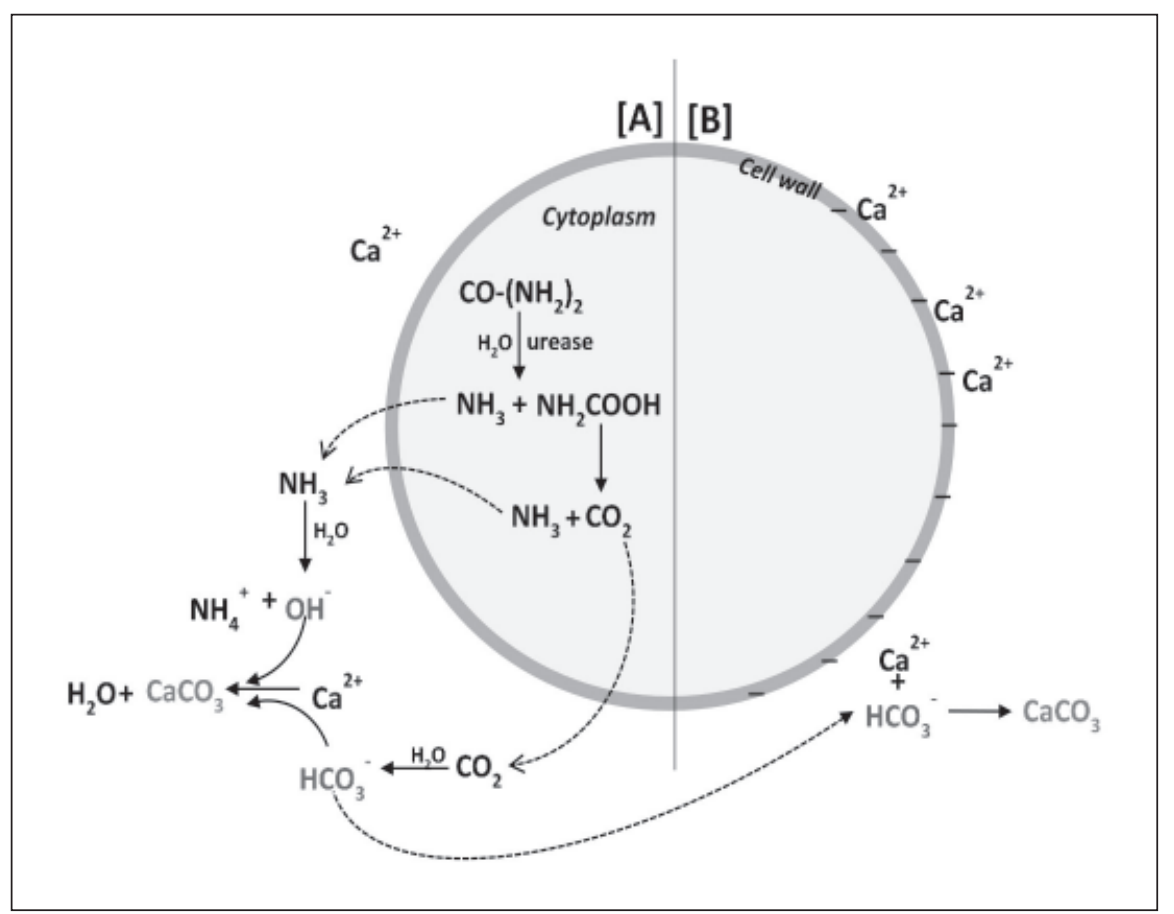

Fig. 1. Summary of calcium carbonate $\left(\mathrm{CaCO}_{3}\right)$ formation via two methods; [A] Net breakdown of urea producing $\mathrm{NH}_{3}$ and $\mathrm{CO}_{2}$ which later were broken to form $\mathrm{OH}^{-}$and $\mathrm{HCO}_{3}{ }^{-}$ions, respectively and combine with $\mathrm{Ca}_{2}{ }^{+}$from the environment; [B] Negatively charged bacteria well call attract $\mathrm{Ca}_{2}{ }^{+}$and form a 'nucleus' for $\mathrm{HCO}_{3}{ }^{-}$attachment and form $\mathrm{CaCO}_{3}$. 
straining (Burbank et al., 2011). Harkes et al. (2010) recommend that the bacterial suspension should first be injected followed by cementation solution for uniform distribution of bacterial activity and precipitation of calcite. Kalantary and Kahani, (2015) demonstrated that the application of biological precipitation on a poorly graded sandy soil increased the unconfined compressive strength (UCS) of the soil up to a range of $100-400 \mathrm{KPa}$. This amount of unconfined compressive strength (UCS) satisfies the range for several soil improvement projects. This was achieved due to calcite deposition by bacterial activity (Figure 2), which enhances the physicomechanical characteristics of the sandy soil by sticking together sand particles. The sand particles bonding further paves the way towards the stabilization of dispersive sand particles against erosion (Moravej et al., 2018).

MICP technique has also been promising for in situ application as it enhances the cyclic strength of silty sands within the range of $0-35 \%$ fines content, due to its compatibility with the silty sands diminutive pore size (Zamani \& Montoya, 2019). Also, to intensify the MICP technique for soil improvement, the cementation reagent and the concentration of urease-producing microorganisms are increased within the soil matrix. One of the successful MICP methods of introducing the cementation reagent and microorganisms into the soil matrix to improve its engineering characteristics such as permeability, unconfined compressive strength, shear strength, hydraulic conductivity, and stiffness is biogrout (Kumari \& Xiang, 2017). Biogrout is a sand consolidation technique achieved with the release of $\mathrm{CO}_{3}{ }^{2-}$ from the hydrolysis of urea in the presence of $\mathrm{Ca}^{2+}$ to form $\mathrm{CaCO}_{3}$ in situ (Omoregie et al., 2018). This process is greatly enhanced using microorganisms with high urease activity. The microorganisms are introduced into the soil matrix through three main methods: (i) percolation; (ii) premixing method and (iii) injection.

The percolation method simply implies spraying or trickling cementation solution with bacterial suspension onto the soil surface which penetrates the soil matrix under the influence of gravity (Seifan $\&$ Berenjian, 2019). The method is relatively cheap as no heavy machinery is required for solution injection into the soil. However, its efficiency is limited to the treatment of fine-grained soils such as silt and clay due to low permeability and infiltration rate (Mujah et al., 2017). While the premixing method is another process to introduce potent microbial strain into the treated soil matrix by the mechanical mixing of soil with bacteria. The technique is relatively costly and requires a higher source of energy when compared with the trickling method. However, its effectiveness is higher, especially in deeper levels of soil (Seifan \& Berenjian, 2019).

The injection method approach is the most preferable MICP treatment technique that involves the introduction of the biological healing agent deep into the soil from top to bottom (Mujah et al., 2017). This process lies on injection parameters such as flow rate and pressure which can be easily controlled and

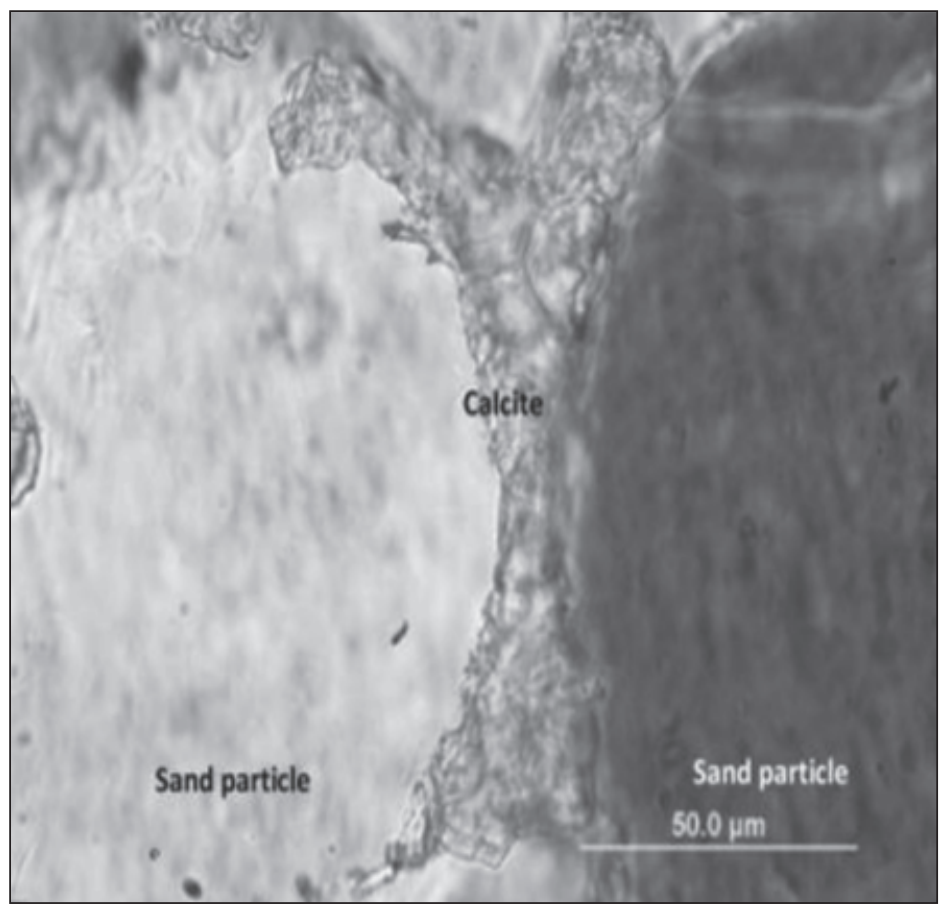

Fig. 2. Two sand particles bonded by calcite crystals precipitated by ureolytic bacteria (Al-Thawadi, 2011). 
allows injection of the bacteria solution in both horizontal and vertical directions (Seifan \& Berenjian, 2019). However, uneven distribution of bacteria and nonuniformity of precipitated $\mathrm{CaCO}_{3}$ in tested sand columns are the major disadvantages of this method. An investigation on the various MICP injection scenarios was reported by Shahrokhi-Shahraki et al. (2015) and suggested four strategies to prevents the occurrence of excessive crystal accumulation nearby the injection point and enhance the homogenous distribution of $\mathrm{CaCO}_{3}$ crystal formation over a great length in the sand specimen. Those strategies are: (i) mixing the cementation solutions with bacterial cell before injecting into the soil matrix; (ii) two-phase injection involves the injection of the bacterial cell solution before cementation solution; (iii) staged injection, with or without retention periods between the injection phases and (iv) single-phase injection involves the injection of reagents simultaneously into the sands.

\section{MICROBIAL UREASE ACTIVITY FOR MICP}

The bacteria's core roles during the biochemical reactions include the generation of an alkaline environment via different physiological actions and the production of urease enzymes. The enzyme urease activity is controlled by natural environmental factors that influence the occurrence of these reactions (Okwadha \& Li, 2010). If the reactions can occur within unconsolidated sand pores, a sandstone-like material is formed due to bonding together of the sand particles (Jiang et al., 2016). Ureolysis that is mediated microbially occurs more rapidly than the uncatalyzed rate by approximately $10^{14}$ times (Tobler et al., 2011). Although, there are different opinions with regards to the role of bacteria in $\mathrm{CaCO}_{3}$ precipitation through ureolysis; the precipitation is (i) an accidental and unwanted by-product of microbial metabolism, and (ii) a specific process that ecologically benefits precipitating microbes (Seifan \& Berenjian, 2019).

The production of urease enzyme by soil bacteria provides the simulative biomineralization application process via ureolysis possible and potentially useful for various soil engineering applications (Burbank et al., 2012). In brief, the production of urease has been demonstrated to be inducible, constitutive, and repressible. Bacterial species with calcite precipitating potential, produce urease and these bacteria reported in literature include; Pararhodobacter sp., Bacillus massiliensis, B. licheniformis, B. sphaericus, $B$. magatarium, Arthrobacter crystallopoietes, Lysinibacillus fusiformis, Sporosarcina pasteurii, S. soli, and Morganella morgana (Park et al., 2010;
Helmi et al., 2016; Fujita et al., 2017; Moravej et al., 2018; Duo et al., 2018; Mukherjee et al., 2019).

\section{MORPHOLOGY OF PRECIPITATED CALCIUM CARBONATE CRYSTALS}

The precipitation of calcium carbonate forms various polymorphs distributed as minerals in nature (Liu et al., 2017). These include the anhydrous polymorphs namely, calcite, aragonite, and vaterite with the most thermodynamically stable anhydrous $\mathrm{CaCO}_{3}$ polymorph at ambient conditions is calcite. The formation behavior with regards to each polymorph is influenced by synthesis factors such as temperature, $\mathrm{pH}$, ratio and concentration of calcium and carbonate ions, reaction time, additives, etc. (Chang et al., 2017a; Chang et al., 2017b). The crystal structure of calcite is rhombohedral while aragonite and vaterite are orthorhombic and hexagonal respectively (Oral \& Ercan, 2018). There are also two hydrated phases which are monohydrate calcium carbonate $\left(\mathrm{CaCO}_{3} \cdot \mathrm{H}_{2} \mathrm{O}\right)$ and hexahydrate calcium carbonate $\left(\mathrm{CaCO}_{3} \cdot 6 \mathrm{H}_{2} \mathrm{O}\right)$, in addition to different amorphous calcium carbonate (ACC) polymorphs (Krajewska, 2018).

$\mathrm{CaCO}_{3}$ is first precipitated from supersaturated solutions as an unstable ACC, which is converted to vaterite spontaneously. This conversion of metastable vaterite to calcite takes place in the presence of water over a short duration of time, with virtually all vaterite transformed to calcite within 24 hr (Burbank et al., 2011). The solubility of calcium carbonate polymorphs is in increasing order of calcite, aragonite, vaterite, and ACC (Chang et al., 2017a). Lower solubility product values of aragonite and vaterite indicate the difficult nature of obtaining these polymorphs as a result of their unstable characteristics (Oral \& Ercan, 2018). ACC can be converted to a more thermodynamically stable polymorph of $\mathrm{CaCO}_{3}$ such as vaterite, aragonite, and calcite when suspended in an aqueous solution at ambient temperature (Seifan \& Berenjian, 2019).

The precipitation of the polymorphs of vaterite, aragonite, and calcite depend both on bacterial strains and their growing environment (Jones, 2017). It was observed that different bacteria precipitate calcium carbonate of various types and were mainly either polyhedral or spherical crystalline forms. Emerging evidence propose that bacteria do not have a direct effect on the selection of calcium carbonate polymorph or morphology. Thus, the morphological features may be influenced by the composition of the culture medium and the chemical nature of the specific bacterial outer structures consisting of proteins, lipids, nucleic acids, and polysaccharides, 
which might be essential for the process of bacterial crystallization (Wei et al., 2015; Kim et al., 2016).

\section{FACTORS AFFECTING MICP EFFICIENCY}

The chemical process involved in $\mathrm{CaCO}_{3}$ precipitation is usually governed by four main parameters; $\mathrm{pH}$, the concentration of dissolved inorganic carbon, calcium concentration, and availability of bacteria nucleation sites (Hammes \& Verstraete, 2002; Omoregie et al., 2018). The first three aforementioned factors influence the carbonate ions concentration while the nucleation site plays a vital role in the stable and continuous formation of calcium carbonate by bacteria (Rodriguez-Navarro et al., 2012; Anbu et al., 2016). MICP as a biological process is influenced by a large number of abiotic and biotic factors influencing its successful completion. These factors include; bacterial genotype, bacteria cell concentration, nutrients, geometric compatibility of bacteria, reactant concentration, temperature, $\mathrm{pH}$, availability of moisture, level of aeration, and quality of water $(\mathrm{Ng}$ et al., 2012; Al-salloum et al., 2017).

\section{Temperature}

MICP is highly influenced by temperature as it affects the microorganisms' urease activity, solubility, nucleation rate, and growth of $\mathrm{CaCO}_{3}$ crystals (Mujah et al., 2017). The temperature may vary with altitude, latitude, moisture content, incident solar radiation, depth of soil, and type of soil $(\mathrm{Ng}$ et al., 2012). Previous studies have demonstrated that increasing temperature from $10^{\circ} \mathrm{C}$ to $15^{\circ} \mathrm{C}$ and 15 to $20^{\circ} \mathrm{C}$ enhances the rate of ureolysis by twice and five times, respectively (Nemati \& Voordouw, 2003; Ferris et al., 2004; Umar et al., 2016). Also, raising the temperature from $20^{\circ} \mathrm{C}$ to $50^{\circ} \mathrm{C}$ promotes the rate of $\mathrm{CaCO}_{3}$ production and influences the shape and size of $\mathrm{CaCO}_{3}$ crystals formed (Mujah et al., 2017). Any rise in temperature within this temperature range increases the precipitation rate and therefore more $\mathrm{CaCO}_{3}$ is precipitated. This might be due to the high ureolytic activity of the bacterial solution within the temperature range leading to relatively large amounts of induced $\mathrm{CaCO}_{3}$ during the MICP treatment process (Peng \& Liu, 2019). The rate of ureolysis is marginally higher at $30^{\circ} \mathrm{C}$ and any increase in temperature above $30^{\circ} \mathrm{C}$ does not promote the rate of decomposition (Nemati et al., 2005). This is a clear indication that any rise in temperature within the optimum range speeds up the rate of urea hydrolysis depending on other conditions such as reactants concentration within the system and environmental conditions (Umar et al., 2016). Kim et al. (2018) researched the effect of temperature on MICP using two microbial species Sporosarcina pasteurii and
Staphylococcus saprophyticus, and reported that the maximum calcite precipitation was measured at a temperature of $30^{\circ} \mathrm{C}$, while the least precipitation was observed at a temperature of $50^{\circ} \mathrm{C}$ that caused about 30 to $40 \%$ of the precipitation is reduced than the amount precipitated at the optimum temperature of $30^{\circ} \mathrm{C}$. Moreover, the solubility of $\mathrm{CaCO}_{3}$ decreases with a rise in temperature over the optimum temperature range, thus affecting precipitation. This showing that temperature is the most critical factor influencing the formation of $\mathrm{CaCO}_{3}$ polymorphs (Okwadha \& Li, 2010). The precipitation of supersaturated solutions of $\mathrm{Ca}^{2+}$ and $\mathrm{CO}_{3}{ }^{2-}$ initially formed ACC which is transformed into crystalline $\mathrm{CaCO}_{3}$ polymorphs, mainly forming vaterite and calcite at a low-temperature range of $14-30^{\circ} \mathrm{C}$ while at a higher temperature range of $60^{\circ} \mathrm{C}$ to $80^{\circ} \mathrm{C}$ aragonite and calcite are formed (Chang et al., 2017a).

\section{$p H$}

The $\mathrm{pH}$ of the bacterial medium plays a significant role in inducing microbial morphological changes, affect its stability and instigate its enzyme secretion (Omoregie et al., 2017a). The presence of hydroxyl ions $\left(\mathrm{OH}^{-}\right)$formed from the generation of ammonium ions $\left(\mathrm{NH}_{4}^{+}\right)$during neurolysis, changed the $\mathrm{pH}$ level, thus creating an alkaline environment suitable for the precipitation of $\mathrm{CaCO}_{3}$ (DeJong et al., 2010; Mujah et al., 2017). Microbial ureases' optimum $\mathrm{pH}$ is approximately neutral, except for a few groups of acid ureases. Urease activity of alkalo-tolerant bacteria, for example, $S$. pasteurii have an optimum $\mathrm{pH}$ of 8.0. However, the microbial urease could be denatured irreversibly at a $\mathrm{pH}$ lower than $5.0(\mathrm{Ng}$ et al., 2014). The amount of $\mathrm{CaCO}_{3}$ precipitated increases with $\mathrm{pH}$ and converges at a $\mathrm{pH}$ range of 8.7 to 9.5 (Kim et al., 2018).

\section{Bacteria cell concentration}

Bacterial cells are a definite nucleation site for $\mathrm{CaCO}_{3}$ precipitation, their concentration in surface treatment solution, bio-mortar, or inactive matrices is a significant factor for effective MICP application techniques (Al-salloum et al., 2017). The availability of nucleation sites is important in governing the urease activity that determines the amount of $\mathrm{CaCO}_{3}$ produced (Xu et al., 2014). Also, when the soil matrix contains more bacterial cells, the produced $\mathrm{CO}_{3}{ }^{2-}$ ions would be consumed mainly by nucleation of new calcium carbonate crystals, as a result of the abundant nucleation sites, rather than growing the existing $\mathrm{CaCO}_{3}$ crystals, leading to the precipitation of more small $\mathrm{CaCO}_{3}$ crystals (Al-Thawadi \& CordRuwisch, 2012; Mujah et al., 2017). However, the optimum $\mathrm{CaCO}_{3}$ precipitated can only be attained within the concentration of bacteria cells from $10^{5}$ to $10^{8}$ cells $\mathrm{mL}^{-1}$ (Okwadha \& Li, 2010; Mondal \& Ghosh, 2018). 


\section{Nutrients}

Nutrients serve as the energy sources of bacteria; thus, it is important to provide proper and adequate nutrients for $\mathrm{CaCO}_{3}$ producing bacteria. The common bacteria nutrients include $\mathrm{N}, \mathrm{CO}_{2}, \mathrm{Ca}$, $\mathrm{K}, \mathrm{Fe}, \mathrm{Mg}, \mathrm{P}$, and are supplied to the bacteria throughout the culture and soil treatment stage $(\mathrm{Ng}$ et al., 2012). Ureolytic bacteria utilize urea as a sole nitrogen source, while the calcium source may be calcium chloride, calcium chloride dihydrate, calcium nitrate, or calcium lactate (Siddique \& Chahal, 2011; Navneet et al., 2016). It is noteworthy that organic calcium source such as calcium lactate provides additional nutritional requirements for bacterial growth, hence more beneficial for microbial precipitation of $\mathrm{CaCO}_{3}(\mathrm{Xu}$ et al., 2015). The dissolved inorganic carbon generated from the extracellular polysaccharide of the bacteria complexes the calcium ions, thereby reducing $\mathrm{CaCO}_{3}$ saturation and enhancing the $\mathrm{CaCO}_{3}$ precipitation (Sarayu et al., 2014).

\section{Types of bacteria}

Bacterial type is significant to the production of urease activity. There are different types of bacteria capable of producing different amounts of urease and $\mathrm{CaCO}_{3}$ precipitation. The bacteria suitable for MICP should be able to catalyze the hydrolysis of urea via the production of urease enzyme (Krajewska, 2018; Mondal \& Ghosh 2019; Zhao et al., 2019; Lapierre et al., 2020; Marin et al., 2021; Saneiyan et al., 2021). These bacteria should neither be modified genetically nor enclose any exchangeable elements capable of enhancing the pathogenicity of other microbes within the environment (Okwadha \& Li, 2010). Thus, the bacteria should be alkalophilic, non-pathogenic, and possess high ureolytic efficiency with the ability to homogeneously precipitate calcite within the substratum (Khamehchiyan et al., 2015).

The bacterial strain plays a significant role in the crystal size, morphology, form, and biochemistry of $\mathrm{CaCO}_{3}$, thus makes the selection of bacteria is crucial for a successful solidification due to varies of the production urease and the amount of $\mathrm{CaCO}_{3}$ produced in MICP varied with the type of bacterial strain (Xu et al., 2014; Fujita et al., 2017; Seifan \& Berenjian, 2019). Typical urease-producing bacteria are genera Desulfotomaculum, Bacillus, Spoloactobacilus, Clostridium, and Sporosarcina (Sarayu et al., 2014). The most preferable bacteria are aerobic bacteria that capable of producing $\mathrm{CO}_{2}$ during cell respiration. This released $\mathrm{CO}_{2}$ is parallel to $\mathrm{pH}$ rise due to the production of ammonium ( $\mathrm{Ng}$ et al., 2012). The most cited bacteria for MICP is $S$. pasteurii due to its large amount of $\mathrm{CaCO}_{3}$ precipitation, high urease activity, tolerance to high $\mathrm{pH}$, and precipitation of a large amount of calcite
(Rowshanbakht et al., 2016; Minto et al., 2018; Ruan et al., 2019).

\section{Nature and concentration of reactants}

Application of urease-producing bacteria towards attaining MICP necessitates the use of urea as a nitrogen source (Tirkolaei \& Bilsel, 2015). An ideal urea and calcium chloride concentration is significant in achieving precipitation of calcite. In terms of weight, urea $\left(\mathrm{CO}\left(\mathrm{NH}_{2}\right)_{2}\right)$ and calcium chloride dihydrate $\left(\mathrm{CaCl}_{2} \cdot 2 \mathrm{H}_{2} \mathrm{O}\right)$ stoichiometric ratio of 2.5 is critical ( $\mathrm{Ng}$ et al., 2012). Muynck et al., (2010) reported that the best concentrations of urea and $\mathrm{CaCl}_{2}$ are $0.5 \mathrm{M}$ and $0.25 \mathrm{M}$, respectively. However, in a few other studies, the efficiency of calcite precipitation and the average size of $\mathrm{CaCO}_{3}$ crystals increases with low concentrations of urea and calcium chloride $(<0.25 \mathrm{M})$ and concentration of more than $0.5 \mathrm{M}$ will decrease the efficiency of calcite precipitation but depends on the species of bacteria. (Okwadha \& Li, 2010; Al-Thawadi \& Cord-Ruwisch, 2012; Lia et al., 2018; Golavkina et al., 2020; Liu et al., 2021). Since enzymatic hydrolysis of urea generates ammonia which increases the $\mathrm{pH}$, it is mandatory to be used with calibrated discretion to avoid inhibiting bacterial growth due to excessive alkalinity (Muynck et al., 2010). Ultimately, for $\mathrm{CO}_{3}{ }^{-}$ 2 to react with available $\mathrm{Ca}^{2+}$ in the system, there must be an equivalent amount of calcium source supplemented with urea (Siddique \& Chahal, 2011). These two compounds together may generate impurities for the cement, as such should be used in minimal quantity to achieve the maximum possible advantage of calcification (Al-salloum et al., 2017).

\section{APPLICATIONS OF MICP}

MICP technique is an effective and environmentally friendly technology that can be applied to solve various environmental problems, such as cementation, crack remediation in concrete, bioconsolidation, $\mathrm{CO}_{2}$ sequestration, remediation of heavy metals and radionuclides, and other essential applications (Umar et al., 2016; Al-salloum et al., 2017; Arias et al., 2017; Omoregie et al., 2018; Mutitu et al., 2019).

\section{Remediation of cracks}

In concrete, crack forms due to several mechanisms such as aging, freeze-thaw reactions, mechanical compressive, and tensile forces (Anbu et al., 2016). Cracks in the concrete lead to corrosion of embedded steel via easy ingress of ions and moisture that react with reinforcements in concrete and expansive stressed which leads to spalling. There are several methods employed for crack 
remediation concrete but most are polymer-based which have a severe effect on the strength of the material (Al-salloum et al., 2017). In case of remediation of cracks in concrete structures, MICP has proved its efficacy in several reports It involves the supplementation of concrete structures with bacteria and nutrients as healing agents to stimulate the remediating action of sealing cracks and is identified as a self-healing approach (Vijay et al., 2017; Jongvivatsakul et al., 2019; Ruan et al., 2019; Liu et al., 2020; Sun \& Miao 2020; Fun et al., 2021).

There are different methods employed to incorporate self-healing agents into the concrete matrix to activate its healing property whenever a crack appears in a structure. These mechanisms are broadly classified as vascular-based, intrinsic-based, and capsule-based (Joshi et al., 2017). (i) Vascularbased self-healing mechanism involves the supplying of healing material from outside of the structure using distributed vascular channels embedded in a concrete matrix (Joshi et al., 2017). As cracks appear, healing material moves through the channels due to pressure gradient between cracks position and agent source (Seifan et al., 2016) (ii) In intrinsic selfhealing; the embedded materials in the concrete matrix has a latent self-healing function which might be triggered by external stimulus or damage (Joshi et al., 2017). (iii) Capsule-based self-healing mechanism involves the use of capsules to store healing agents which are released into the concrete matrix when the capsules are triggered by rupture or external stimulus (Xu \& Wang, 2018).

An investigation carried out by Li et al. (2018) on the consolidation of cracks produced in masonry cement mortars revealed that the bio-consolidation results in a significant reduction in water absorption and positively influence improvement in compressive strength of mortars. A similar study by Algaifi et al. (2018) using Lysinibacillus sphaericus as a microbial agent for crack self-healing concrete demonstrated that a crack of $0.4 \mathrm{mM}$ wide was completely sealed with calcite after 60 days. At time 42 days, the predicted crack healing was $58 \%$ with the healing ratio increasing with time. This was supported by Zhang et al. (2019) who reported a maximum value of completely self-healed crack of width $1.22 \mathrm{~mm}$ using open cultures of microbial consortia after 28 days of healing. Also, the microbial consortia result in a $61 \%$ decrease in the cost of production when compared to pure cultures.

\section{$\mathrm{CO}_{2}$ Sequestration}

The increase in high concentrations of greenhouse gas emissions in the atmosphere results in environmental disasters such as global warming (Jacobs et al., 2017). The most abundant emitted greenhouse gas is $\mathrm{CO}_{2}$, which significantly affects the earth's climate (Srivastava et al., 2014). $\mathrm{CO}_{2}$ sequestration alleviates the released $\mathrm{CO}_{2}$ from the atmosphere (Phillips et al., 2013a; Krajewska, 2018). The proposed ways of reducing $\mathrm{CO}_{2}$ emission into the atmosphere include; the use of energy sources such as solar, wind, and nuclear energy which are less carbon-intensive, or by increasing the efficiency of energy utilization, from production to end-use, but none of these options are practically possible (Dhami et al., 2013).

Sequestration of $\mathrm{CO}_{2}$ is naturally achieved by chemical fixation of $\mathrm{CO}_{2}$ at a very slow reaction rate to form carbonate like calcite, magnesite, aragonite, and dolomite (Anbu et al., 2016). MICP has been examined to be a potential technology for the sequestration of $\mathrm{CO}_{2}$ (Achal \& Mukherjee, 2015). In this technique, $\mathrm{CO}_{2}$ is transformed into carbonate of different crystals like calcite, magnesite, aragonite, and dolomite (Srivastava et al., 2014). The technique is eco-friendly and safer than conventional methods of sequestration of $\mathrm{CO}_{2}$ (Anbu et al., 2016). The biological sequestration of $\mathrm{CO}_{2}$ into environmentally friendly and stable mineral carbonates utilizes bacterial carbonic anhydrases extracted from the pure culture of high urease-producing bacteria such as Bacillus cereus (Li et al., 2013). This was supported in a study by Okyay et al., (2016) which revealed the potential of ureolytic microbial consortia towards the sequestration of $\mathrm{CO}_{2}$. It was observed from the study that the sequestration was higher in consortia with low diversity than in a very diverse consortium. The sequestered $\mathrm{CO}_{2}$ can be stored permanently as an inert solid stable inorganic carbonate and has several potential industrial applications such as paints, paper, food, pharmaceuticals, cement, sealants, adhesives, and construction materials (Chang et al., 2017b).

\section{Remediation of heavy metals and radionuclides}

Rapid industrialization has led to the accumulation of radionuclides and heavy metals contaminants that resulted in both environmental and human health problems. These pollutants include heavy metals such as copper, cadmium, arsenic, antimony, chromium, lead, tin, cobalt, mercury, zinc, and radionuclides such as uranium, thorium, radium, and strontium (Arias et al., 2017). The major threat with radionuclides and heavy metals is that they are not biologically or chemically degradable, once used or released into the environment (He \& Chen, 2014; Nigro et al., 2017). Conventional methods of metal contaminant treatment in soil include Physicochemical techniques associated with high costs, energy, and chemical consumption with possible emission of secondary pollutants (Kumari et al., 2016).

The application of biological treatment of metals from contaminated sites through bioaccumulation, bioleaching, bioimmobilization, biocoagulation, 
phytoremediation, and absorbents have also not been effective because they are time-consuming, expensive, and may result in the release of absorbed or immobilized heavy metals back to the environment (Anbu et al., 2016). This paved way for the novel applications of urease-producing organisms in the bioremediation of heavy metals and radionuclides to form insoluble metal-containing carbonates (Kumari et al., 2016). During the process, biomineralization of heavy metals and radionuclides occurs as a competitive co-precipitation reaction whereby suitable divalent cations are incorporated within the calcite lattice (Dhami et al., 2013). Several authors have reported the potential application of MICP to remediate radionuclides such as strontium and heavy metals such as cadmium and lead from the environment (Achal et al., 2012a; Achal et al., 2012b; Mwandira et al., 2017; Zhao et al., 2019).

\section{Other essential applications}

MICP is a potential technology for the removal of calcium from the environment (Anbu et al., 2016). Excess calcium ions present in wastewater generate serious operational problems which include scaling in reactors and pipelines due to its precipitation as phosphate, sulfate, and or carbonate salt but the application of ureolytic bacteria in the biomineralization process of calcium ions removal from wastewater is poorly described (Arias et al., 2017). A study developed by Hammes et al. (2003) on the removal of calcium from industrial wastewater reported the removal of calcium over $90 \%$ in the period under experiment mediated by ureolytic microbiological carbonate precipitation through the use of a semi-continuous reactor system. In another study, heterotrophic bacteria isolated from submerged fixed-film bioreactor meant for urban wastewater treatment carried out the precipitation of carbonates crystals. This biological activity could be applied in calcium capture in the treatment of urban wastewater (Uad et al., 2014).

Polychlorinated biphenyls (PCBs) contaminated oil is a recalcitrant contaminant comprising severe environmental concern and conventional methods available for the removal of PCBs include hydro blasting, solvent washing, or sandblasting followed by encapsulation in the epoxy coating, but all these methods are not effective because of the resurfacing of oil over time (Phillips et al., 2013b). Alternatively, microbial processes are now used in the removal of these recalcitrant contaminants (Omoregie et al., 2018). Sporosarcina pasteurii was used to generate a biosealant that reduced water permeability on the surface of PCB-contaminated concrete by a magnitude of $1-5$ orders with high resistance to carbonation (Okwadha \& Li, 2011).

Mortar is a workable paste usually consisting of aggregates, water, and binder for binding building materials and filling the gaps between them (Muynck et al., 2010). Specifically, a biological mortar consists of a mixture of nutritional medium containing calcium salt with bacteria and finely ground limestone, usually used to avoid the problems associated with the physical and chemical incompatibilities of the underlying material (particularly brittle materials) with commonly used repair mortars (Muynck et al., 2010). Several studies have demonstrated the potential application of MICP towards improving the compressive strength of mortar (Park et al., 2010; Kanta et al., 2016; Choi et al., 2017). In a study by Elmanama and Alhour (2013) the inclusion of ureolytic Bacillus mycoides in cement mortar enhances the compressive strength of the cement mortar to a maximum increase of $17 \%$ and recorded a $32 \%$ reduction in water absorption.

In addition to the applications mentioned above, MICP can be a potentially promising technique for other essential applications. While developing a green biodegradable film, red seaweed was used as a base matrix and microbially induced $\mathrm{CaCO}_{3}$ precipitated by Bacillus sphaericus as a filler for enhancing the red seaweed material properties for plasticulture purpose (Abdul Khalil et al., 2018). Application of MICP for the biosynthesis of fluorescent Cadmium Sulphide (CdS) nanoparticles has been demonstrated by Zhu et al. (2016) using a urease-producing bacterium Citrobacter braaki isolated from the calcium-rich shells of abalone.

\section{LIMITATIONS OF MICP}

MICP can be scored high as construction sustainability due to its scope for recycling and low energy requirement. However, the safety of MICP application for various construction purposes is of great concern (Omoregie et al., 2017b). MICP is not perfectly eco-friendly due to the production of ammonia as a by-product and its oxidized by-product nitrate during the ureolysis-driven process (Soon, 2013). These gases are toxic to soil microorganisms and highly detrimental to human health, particularly at high concentrations (Omoregie et al., 2017a). Hence, it is significant to avoid ammonia contaminating the environment through the development of strategies such as treatment of the MICP released ammonia before discharge and possible utilization of the ammonia as fertilizer by surrounding plants (Mujah et al., 2017). The use of the facial mask is highly recommended for protection against the release of these gases by ureolytic bacteria during handling (Omoregie et al., 2016).

MICP is considered expensive for field-scale applications or commercial implementation, especially when compared with conventional cementitious composites (Mujah et al., 2017). The aseptic 
production of bacteria spores, labor required, protective material and nutrients contribute to high cost thus pose a threat to bacterial technological cementitious composites application (Xu \& Wang, 2018; Li et al., 2019). The laboratory-grade nutrient medium for bacteria cultivation alone can cost as high as $60 \%$ of the entire production cost (Omoregie et al., 2019). However, the utilization of industrial byproducts or wastes as an alternative nutritional source for bacteria cultivation can limit the economic challenges of MICP (Achal \& Mukherjee, 2015). Cheng et al. (2014) proposed the potential use of seawater rich in calcium ions as the main calcium source for calcite precipitation during the MICP technique. The experimental results revealed that the UCS of the treated sand recorded two times higher strength (with the same amount of crystal precipitated) than MICP treatment with higher concentrated solutions of calcium and urea, retaining permeability at about $30 \%$ which signifies a good drainage ability. Further studies should be carried out on the possibility of utilizing this method for a sustainable and cost-effective way of strengthening the soil.

Other challenges include a reduction in the population of the introduced bacteria into the soil, due to competition, predation, and stress arising from abiotic factors like osmotic pressure, $\mathrm{pH}$, availability of suitable nutrients, and temperature (Burbank et al., 2011). Proffering solutions to the above-mentioned limitations are significant for an effective field-scale application of the MICP technique.

\section{CONCLUSION}

This paper reviewed the eco-friendly ground improvement technique using bio-mineralization known as MICP. A vast range of potential applications of MICP continues to expand with the rapid development of MICP technology. However, there is uncertainty in the method of microorganism application such as injection and optimization of urease activity in the soil. Currently, biogrout is the best application method available where it enhanced the release of $\mathrm{CO}_{3}{ }^{2-}$ in the presence of $\mathrm{Ca}^{2+}$ to form $\mathrm{CaCO}_{3}$. MICP is much influenced by abiotic and biotic factors where the release of $\mathrm{CO} 2$ from anaerobic bacteria respiration enhances the $\mathrm{CaCO} 3$ formation with stabilization of $\mathrm{pH}$ and temperature will ensure the bacteria growth at the optimum level. Though, the $\mathrm{CO}_{3}{ }^{2-}$ concentration is still the vital factor in the continuous formation of $\mathrm{CaCO}_{3}$ by bacteria. Biomineralization plays a significant role in improving soil and sand engineering characteristics for different geotechnical applications. A vast range of potential applications of MICP continues to expand with the rapid development of MICP technology. Still, its effectiveness is limited to several shortcomings associated with its industrial application since most of the previous studies on microbial geotechnology are at the field trial stage. This review recommends further interdisciplinary research to overcome the challenges of this technology before effective largescale or commercial applications.

\section{ACKNOWLEDGEMENT}

The authors would like to acknowledge Universiti Putra Malaysia for the financial support through Geran Universiti Putra Malaysia (Grant No: GP-IPS/ 2020/9691000).

\section{REFERENCES}

Abdul Khalil, H.P.S., Chong, E.W.N., Owolabi, F.A.T., Asniza, M., Tye, Y.Y., Tajarudin, H.A. \& Rizal, S. 2018. Microbial-induced $\mathrm{CaCO}_{3}$ filled seaweed-based film for green plasticulture application. Journal of Cleaner Production, 199: 150-163.

Achal, V., Pan, X. \& Zhang, D. 2012a. Bioremediation of strontium $(\mathrm{Sr})$ contaminated aquifer quartz sand based on carbonate precipitation induced by $\mathrm{Sr}$ resistant. Halomonas sp. Chemosphere, 89(6): 764-768.

Achal, V., Pan, X., Zhang, D. \& Fu, Q. 2012 b. Bioremediation of $\mathrm{Pb}$-Contaminated Soil Based on Microbially Induced Calcite Precipitation. Journal of Microbiology Biotechnology, 22(3): 244-247.

Achal, V. \& Mukherjee, A. 2015. A review of microbial precipitation for sustainable construction. Construction and Building Materials, 93: 1224-1235.

Algaifi, H.A., Abu Bakar, S., Abdul Rahman, M.S., Razin, A.Z.A., Shahir, S. \& Ali, W.H.A. 2018. Numerical modeling for crack self-healing concrete by microbial calcium carbonate. Construction and Building Materials, 189: 816824.

Al-salloum, Y., Hadi, S., Abbas, H., Almusallam, T. \& Moslem, M.A. 2017. Bio-induction and bioremediation of cementitious composites using microbial mineral precipitation - A review. Construction and Building Materials, 154: 857876.

Al-Thawadi, S.M. 2011. Ureolytic bacteria and calcium carbonate formation as a mechanism of strength enhancement of sand. Journal of Advanced Science and Engineering Research, 1: $98-114$. 
Anbu, P., Kang, C.H., Shin, Y.J. \& So, J.S. 2016. Formations of calcium carbonate minerals by bacteria and its multiple applications. Springer Open Journal, 5(1): 1-26.

Arias, D., Cisternas, L. \& Rivas, M. 2017. Biomineralization mediated by ureolytic bacteria applied to water treatment: A review. Crystals, 7(11): 345-360.

Azaïs, T., Von Euw, S., Ajili, W., Auzoux-Bordenave, S., Bertani, P., Gajan, D. \& Lesage, A. 2019. Structural description of surfaces and interfaces in biominerals by DNP SENS. Solid State Nuclear Magnetic Resonance, 102: 2-11.

Bibi, S., Oualha, M., Ashfaq, Y. \& Suleiman, T. 2018. Ureolytic bacteria of Qatari soil and their potential in microbially induced calcite precipitation (MICP) for soil stabilization. RSC Advances, 8: 5854-5863.

Bissett, A., Beer, D., Schoon, R., Shiraishi, F., Reimer, A. \& Arp, G. 2008. Microbial mediationof stromatolite formation in karst-water creeks. American Society of Limnology and Oceanography, 53: 1159-1168.

Braissant, O., Decho, A.W., Dupraz, C., Glunk, C., Przekop, K.M. \& Visscher, P.T. 2007. Exopolymeric substances of sulfate-reducing bacteria: Interactions with calcium at alkaline $\mathrm{pH}$ and implication for formation of carbonate minerals. Geobiology, 5: 401-411.

Burbank, M.B., Weaver, T.J., Green, T.L., Williams, B. \& Crawford, R.L. 2011. Precipitation of calcite by indigenous microorganisms to strengthen liquefiable soils. Geomicrobiology Journal, 28: 301-312.

Burbank, M.B., Weaver, T.J., Williams, B.C. \& Crawford, R.L. 2012. Urease activity of ureolytic bacteria isolated from six soils in which calcite was precipitated by indigenous bacteria. Geomicrobiology Journal, 29: 389-395.

Chang, R., Choi, D., Kim, M.H. \& Park, Y. 2017 a. Tuning crystal polymorphisms and structural investigation of precipitated calcium carbonates for $\mathrm{CO}_{2}$ mineralization. American Chemical Society, 5(2): 1659-1667.

Chang, R., Kim, S., Lee, S., Choi, S., Kim, M. \& Park, Y. 2017b. Calcium carbonate precipitation for $\mathrm{CO}_{2}$ storage and utilization: A review of the carbonate crystallization and polymorphism. Frontiers in Energy Research, 5: 17-25.

Chang, I., Im, J. \& Cho, G.C. 2016. Introduction of microbial biopolymers in soil treatment for future environmentally-friendly and sustainable geotechnical engineering. Sustainability, 8: 123.
Chaparro-Acuña, S.P., Becerra-Jiménez, M.L., Martínez-Zambrano, J.J. \& Rojas-Sarmiento, H.A. 2017. Soil bacteria that precipitate calcium carbonate: Mechanism and applications of the process. Acta Agronomica, 67(2): 277-288.

Chen, Y., Feng, Y., Deveaux, J.G., Masoud, M.A., Chandra, F.S., Chen, H. \& Feng, L. 2019. Biomineralization forming process and bioinspired nanomaterials for biomedical application: A Review. Minerals, 9(68): 1-21.

Cheng, L., Shahin, M.A. \& Cord-Ruwisch, R. 2014. Bio-cementation of sandy soil using microbially induced carbonate precipitation for marine environments. Geotechnique, 64: 1010-1013.

Choi, S.G., Wang, K., Wen, Z. \& Chu, J. 2017. Mortar crack repair using microbial induced calcite precipitation method. Cement and Concrete Composites, 83: 209-221.

DeJong, J.T., Mortensen, B.M., Martinez, B.C. \& Nelson, D.C. 2010. Bio-mediated soil improvement. Ecological Engineering, 36(2): 197-210.

Dhami, N.K., Reddy, M.S. \& Mukherjee, M.S. 2013. Biomineralization of calcium carbonates and their engineered applications: A review. Frontiers in Microbiology, 4: 314-327.

Duo, L., Kan-liang, T., Hui-li, Z., Yu-yao, W., Kangyi, N. \& Shi-can, Z. 2018. Experimental investigation of solidifying desert aeolian sand using microbially induced calcite precipitation. Construction and Building Materials, 172: 251262.

Elmanama, A.A. \& Alhour, M.T. 2013. Isolation, characterization and application of calcite producing bacteria from urea rich soils. Journal of Advanced Science and Engineering Research, 3(4): 388-399.

Er ${ }^{\circ}$ an, Y.Ç., de Belie, N. \& Boon, N. 2015. Microbially induced $\mathrm{CaCO}_{3}$ precipitation through denitrification: An optimization study in minimal nutrient environment. Biochemical Engineering Journal, 101: 108-118.

Fan, Y., Du, H. \& Wei, H. 2021. Characteristics of soybean urease mineralized calcium carbonate and repair of concrete surface damage. Journal Wuhan University of Technology, Materials Science Edition, 36: 70-76.

Ferris, F.G., Phoenix, V., Fujita, Y. \& Smith, R.W. 2004. Kinetics of calcite precipitation induced by ureolytic bacteria at 10 to $20^{\circ} \mathrm{C}$ in artificial groundwater. Geochimica et Cosmochimica Acta, 68(8): 1701-1710.

Fujita, M., Nakashima, K., Achal, V. \& Kawasaki, S. 2017. Whole-cell evaluation of urease activity of Pararhodobacter sp. isolated from peripheral beachrock. Biochemical Engineering Journal. 124: $1-5$ 
Ganendra, G., De Muynck, W.D., Ho, A., Arvaniti, E.C., Hosseinkhani, B., Ramos, J.A. \& Boon, N. 2014. Formate oxidation-driven calcium carbonate precipitation by Methylocystis parvus OBBP. Applied and Environmental Microbiology, 80: 4659-4667.

Gunjo, K. \& Youn, H. 2016. Microbially induced calcite precipitation employing environmental isolates. Materials, 9: 468-478.

Golovkina, D.A., Zhurishkina, E.V., Ivanova, L.A., Baranchikov, A.E., Sokolov, A.Y., Bobrov, K.S., Masharsky, A.E., Tsvigun, N.V., Kopitsa, G.P. \& Kulminskaya, A.A. 2020. Calcifying bacteria flexibility in induction of $\mathrm{CaCO}_{3}$ mineralization. Life, 10: 317-331.

Hammes, F., Seka, A., De Knijf, S. \& Verstraete, W. 2003. A novel approach to calcium removal from calcium-rich industrial wastewater. Water Research, 37(3): 699-704.

Hammes, F. \& Verstraete, W. 2002. Key roles of pH and calcium metabolism in microbial carbonate precipitation. Reviews in Environmental Science and Biotechnology, 1: 3-7.

Harkes, M.P., Paassen, L.A., Van, Booster, J.L., Whiffin, V.S. \& Loosdrecht, M.C.M.V. 2010. Fixation and distribution of bacterial activity in sand to induce carbonate precipitation for ground reinforcement. Ecological Engineering, 36: 112-117.

He, J. \& Chen, J.P. 2014. A comprehensive review on biosorption of heavy metals by algal biomass: Materials, performances, chemistry, and modelling simulation tools. Bioresource Technology, 160: 67-78.

Helmi, F.M., Elmitwalli, H.R., Elnagdy, S.M. \& ElHagrassy, A.F. 2016. Calcium carbonate precipitation induced by ureolytic bacteria Bacillus licheniformis. Ecological Engineering, 90: $367-371$.

Hiranya, T.N.K., Nakashima, K. \& Kawasaki, S. 2018. Enhancement of microbially induced carbonate precipitation using organic biopolymer. International Journal of Geomate, 14(41): 7-12.

Jacobs, A., Auburger, S., Bahrs, E., Brauer-Siebrecht, W., Christen, O., Götze, P. \& Märländer, B. 2017. Greenhouse gas emission of biogas production out of silage maize and sugar beet - An assessment along the entire production chain. Applied Energy, 190: 114-121.

Jiang, N.-J., Yoshioka, H., Yamamoto, K. \& Soga, K. 2016. Ureolytic activities of a urease-producing bacterium and purified urease enzyme in the anoxic condition: Implication for subseafloor sand production control by microbially induced carbonate precipitation (MICP). Ecological Engineering, 90: 96-104.
Jones, B. 2017. Review of calcium carbonate polymorph precipitation in spring systems. Sedimentary Geology, 353: 64-75.

Jongvivatsakul, P., Janprasit, K., Nuaklong, P., Pungrasmi, W. \& Likitlersuang, S. 2019. Investigation of the crack healing performance in mortar using microbially induced calcium carbonate precipitation (MICP) method. Construction and Building Materials, 212: 737 744.

Joshi, S., Goyal, S., Mukherjee, A. \& Reddy, M.S. 2017. Microbial healing of cracks in concrete: a review. Journal of Industrial Microbiology \& Biotechnology, 44(11): 1511-1525.

Kalantary, F. \& Kahani, M. 2015. Evaluation of the Ability to Control Biological Precipitation to Improve Sandy Soils. Procedia Earth and Planetary Science, 15: 278-284.

Kanta, K.S., Sarkar, P., Davis, R. \& Sathyan, A.K. 2016. Improvement of the mechanical properties of mortar and concrete using ureolytic bacteria. Construction Materials, 171(5): 179-186.

Kawano, M. \& Tokonami, M. 2014. Effect of organic acids on the precipitation rate and polymorphism of calcium carbonate minerals in solution with $\mathrm{Mg}^{2+}$ ions. Clay Science, 18: 1-10.

Khaliq, W. \& Ehsan, M.B. 2016. Crack healing in concrete using various bio influenced selfhealing techniques. Construction and Building Materials, 102: 349-357.

Khamehchiyan, M., Rowshanbakht, K. \& Nikudel, M.R. 2015. Biological improvement of sandy soil by microbial induced carbonate precipitation. Journal of University of Kerbala, 8(3): 100-110.

Khan, M.N.H., Shimazaki, S. \& Satoru, K. 2016. Coral sand solidification test through microbial calcium carbonate precipitation using Pararhodobacter sp. International Journal of Geomate, 11(26): 2665-2670.

Kim, G., Kim, J. \& Youn, H. 2018. Effect of temperature, $\mathrm{pH}$, and reaction duration on microbially induced calcite precipitation. Applied Sciences, 8: 1277-1287.

Kim, H.J., Eom, H.J., Park, C., Jung, J., Shin, B., Kim, W. \& Park, W. 2016. Calcium carbonate precipitation by Bacillus and Sporosarcina strains isolated from concrete and analysis of the bacterial community of concrete. Journal of Microbiology and Biotechnology, 26(3): 540548.

Krajewska, B. 2018. Urease-aided calcium carbonate mineralization for engineering applications: A review. Journal of Advanced Research, 13: 5967. 
Kumari, D., Qian, X.Y., Pan, X., Achal, V., Li, Q. \& Gadd, G.M. 2016. Microbially-induced carbonate precipitation for immobilization of toxic metals. Advances in Applied Microbiology, 94: 79-108.

Kumari, D. \& Xiang, W. 2017. Review on biologically based grout material to prevent soil liquefaction for ground improvement. International Journal of Geotechnical Engineering, 13(1): 48-53.

Lambert, S.E. \& Randall, D.G. 2019. Manufacturing bio-bricks using microbial induced calcium carbonate precipitation and human urine. Water Research, 160: 158-166.

Lapierre, F.M., Schmid, J., Ederer, B., Ihling, N., Büchs, J. \& Huber, R. 2020. Revealing nutritional requirements of MICP relevant Sporosarcina pasteurii DSM33 for growth improvement in chemically defined and complex media. Scientific Report, 10: 22448.

Li, L., Zheng, Q., Li, Z., Ashour, A. \& Han, B. 2019. Bacterial technology-enabled cementitious composites: A review. Composite Structures, 225: 111-170.

Li, M., Fang, C., Kawasaki, S., Huang, M. \& Achal, V. 2018. Bio-consolidation of cracks in masonry cement mortars by Acinetobacter sp. SC4 isolated from a karst cave. International Biodeterioration and Biodegradation, 141: 94100.

Li, M., Fu, Q., Zhang, Q., Achal, V. \& Kawasaki, S. 2015. Bio-grout based on microbially induced sand solidification by means of asparaginase activity. Scientific Reports, 5: 1-9.

Li, W., Chen, W., Zhou, P. \& Yu, L. 2013. Influence of enzyme concentration on bio-sequestration of $\mathrm{CO}_{2}$ in carbonate form using bacterial carbonic anhydrase. Chemical Engineering Journal, 232: 149-156.

Lia, D., Tian, K.-I., Zhang, H.-I., Wu, Y.-Y., Nie, K.-Y. \& Zhang, S.-C. 2018. Experimental investigation of solidifying desert aeolian sand using microbially induced calcite precipitation. Constructions and Building Materials, 172: 251-262.

Liu, Y., Chen, Y., Huang, X. \& Wu, G. 2017. Biomimetic synthesis of calcium carbonate with different morphologies and polymorphs in the presence of bovine serum albumin and soluble starch. Materials Science and Engineering $C$, 79: 457-464.

Liu, S., Du, K., Huang, W., Amini, F. \& Li, L. 2021. Improvement of erosion-resistance of bio-bricks through fiber and multiple MICP treatments. Constructions and Building Materials, 271: 121573.
Liu, B., Zhu, C., Tang, C.-S., Xie, Y.-H., Yin, L.-Y., Cheng, Q. \& Shi, B. 2020. Bio-remediation of desiccation cracking in clayey soils through microbially induced calcite precipitation (MICP). Engineering Geology, 264: 105389.

Mahawish, A., Bouazza, A. \& Gates, W.P. 2018. Improvement of coarse sand engineering properties by microbially induced calcite precipitation. Geomicrobiology Journal, 35(10): 887-897.

Marin, S., Cabestrero, O., Demergasso, C., Olivares, S., Zetola, V. \& Vera, M. 2021. An indigenous bacterium with enhanced performance of microbially-induced Ca-carbonate biomineralization under extreme alkaline conditions for concrete and soil-improvement industries. Aca Biomaterialia, 120: 304-317.

Meister, P. 2013. Two opposing effects of sulfate reduction on carbonate precipitation in normal marine, hypersaline, and alkaline environments. Geological Society of America, 41: 499-502.

Meyer, F.D., Bang, S., Min, S., Stetler, L.D. \& Bang, S.S. 2011. Microbiologically-induced soil stabilization: Application of Sporosarcina pasteurii for fugitive dust control. In GeoFrontiers 2011: Advances in Geotechnical Engineering, 4002-4011.

Minto, J.M., Tan, Q., Lunn, R.J., El, G., Guo, H. \& Cheng, X. 2018. 'Microbial mortar'-restoration of degraded marble structures with microbially induced carbonate precipitation. Construction and Building Materials, 180: 44-54.

Mondal, S. \& Ghosh, A. 2018. Investigation into the optimal bacterial concentration for compressive strength enhancement of microbial concrete. Construction and Building Materials, 183: 202214.

Mondal, S. \& Ghosh, A.D. 2019. Review on microbial induced calcite precipitation mechanisms leading to bacterial selection for microbial concrete. Construction and Building Materials, 225: 6775.

Montaño, S.M., Juan, S., Marriaga, L. \& Brandão, P.F.B. 2017. Isolation and potential biocementation of calcite precipitation inducing bacteria from colombian buildings. Current Microbiology, 12: 1-10.

Moravej, S., Habibagahi, G., Nikooee, E. \& Niazi, A. 2018. Stabilization of dispersive soils by means of biological calcite precipitation. Geoderma, 315: 130-137.

Mujah, D., Shahin, M.A. \& Cheng, L. 2017. State-ofthe-art review of biocementation by microbially induced calcite precipitation MICP for soil stabilization. Geomicrobiology Journal, 34(6): 524-537. 
Mukherjee, S., Sahu, R.B., Mukherjee, J. \& Sadhu, S. 2019. Application of Microbial-Induced Carbonate Precipitation for Soil Improvement via Ureolysis. Ground Improvement Techniques and Geosynthetics 14: 85-94.

Mutitu, K.D., Munyao, M.O., Wachira, M.J., Mwirichia, R., Thiong'o, K.J. \& Marangu, M.J. 2019. Effects of biocementation on some properties of cement-based materials incorporating Bacillus Species bacteria - A review. Journal of Sustainable Cement-Based Materials, 8(5): 309-325.

Muynck, W.D, Belie, N.D \& Verstraete, W. 2010. Microbial carbonate precipitation in construction materials: A review. Ecological Engineering Journal, 36(2): 118-136.

Mwandira, W., Nakashima, K. \& Kawasaki, S. 2017. Bioremediation of lead-contaminated mine waste by Pararhodobacter sp. based on the microbially induced calcium carbonate precipitation technique and its effects on strength of coarse and fine grained sand. Ecological Engineering, 109: $57-64$.

Navneet, C., Anita, R. \& Rafat, S. 2016. Calcium carbonate precipitation by different bacterial strains. African Journal of Biotechnology, 10(42): 8359-8372.

Nemati, M., Greene, E.A. \& Voordouw, G. 2005. Permeability profile modification using bacterially formed calcium carbonate: Comparison with enzymic option. Process Biochemistry, 40(2): 925-933.

Nemati, M. \& Voordouw, G. 2003. Modification of porous media permeability, using calcium carbonate produced enzymatically in situ. Enzyme and Microbial Technology, 33(5): 635642.

Ng, W., Lee, M. \& Hii, S. 2012. An overview of the factors affecting MICP application in soil improvement. International Journal of Civil and Environmental Engineering, 6(2): 188-194.

Nigro, A., Sappa, G. \& Barbieri, M. 2017. Strontium isotope as tracers of groundwater contamination. Procedia Earth and Planetary Science, 17: 352 355.

Nudelman, F. 2015. Nacre biomineralisation: A review on the mechanisms of crystal nucleation. Seminars in Cell and Developmental Biology, 46: $2-10$.

Okwadha, G.D.O. \& Li, J. 2010. Optimum conditions for microbial carbonate precipitation. Chemosphere, 81(9): 1143-1148.

Okwadha, G.D.O. \& Li, J. 2011. Biocontainment of polychlorinated biphenyls (PCBs) on flat concrete surfaces by microbial carbonate precipitation. Journal of Environmental Management, 92(10): 2860-2864.
Okyay, T.O., Nguyen, H.N., Castro, S.L. \& Rodrigues, D.F. 2016. $\mathrm{CO}_{2}$ sequestration by ureolytic microbial consortia through microbially-induced calcite precipitation. Science of the Total Environment. 572: 671-680.

Omoregie, A.I.O, Senian, N., Li, P.Y., Hei, N.L., Ong, D.E.L., Runnie, I.H.G. \& Morin, N.P. 2016. Screening for urease-producing bacteria from limestone caves of Sarawak. Borneo Journal of Resource Science and Technology, 6(1): 37-45.

Omoregie, A.I., Khoshdelnezamiha, G., Senian, N., Ong, D.E.L. \& Nissom, P.M. 2017a. Experimental optimisation of various cultural conditions on urease activity for isolated Sporosarcina pasteurii strains and evaluation of their biocement potentials. Ecological Engineering, 109: 65-75.

Omoregie, A., Ong, D.E.L. \& Nissom, P. 2017 b. Microbial-induced carbonate precipitation using a sustainable treatment technique. International Journal of Service Management and Sustainability, 2: 17-31.

Omoregie, A.I., Ginjom, R.H. \& Nissom, P.M. 2018. Microbially induced carbonate precipitation via ureolysis process: A mini-review. Transactions on Science and Technology, 5(4): 245-256.

Omoregie, A.I., Ngu, L.H., Ong, D.E.L. \& Nissom, P.M. 2019. Low-cost cultivation of Sporosarcina pasteurii strain in food-grade yeast extract medium for microbially induced carbonate precipitation (MICP) application. Biocatalysis and Agricultural Biotechnology, 17: 247-255.

Oral, Ç.M. \& Ercan, B. 2018. Influence of $\mathrm{pH}$ on morphology, size and polymorph of room temperature synthesized calcium carbonate particles. Powder Technology, 339: 781-788.

Park, S.J., Park, Y.M., Chun, W.Y., Kim, W.J. \& Ghim, S.Y. 2010. Calcite-forming bacteria for compressive strength improvement in mortar. Journal of Microbiology and Biotechnology, 20(4): 782-788.

Peng, J. \& Liu, Z. 2019. Influence of temperature on microbially induced calcium carbonate precipitation for soil treatment. PloS One, 14(6): $1-17$.

Phillips, A.J., Lauchnor, E., Eldring, J., Esposito, R., Mitchell, A.C., Gerlach, R. \& Spangler, L.H. 2013a. Potential $\mathrm{CO}_{2}$ leakage reduction through biofilm-induced calcium carbonate precipitation. Environmental Science and Technology, 47(1): 142-149.

Phillips, A.J., Gerlach, R., Lauchnor, E., Mitchell, A.C., Cunningham, A.B. \& Spangler L. 2013b. Engineered applications of ureolytic biomineralization: A review. Biofouling, 29(6): 715733. 
Ramanan, R., Kannan, K., Deshkar, A., Yadav, R. \& Chakrabarti, T. 2010. Enhanced algal $\mathrm{CO}_{2}$ sequestration through calcite deposition by Chlorella sp. and Spirulina platensis in a miniraceway pond. Bioresource Technology, 101: 2616-2622.

Renner, L.D. \& Weibel, D.B. 2011. Physicochemical regulation of biofilm formation. MRS Bulletin, 36(5): 347-355.

Rodriguez-Navarro, C., Rodriguez-Gallego, M., Chekroun, K.B. \& Gonzalez-Muñoz, M.T. 2003. Conservation of ornamental stone by Myxococcus xanthus-induced carbonate biomineralization. Applied and Environmental Microbiology, 69: 2182-2193.

Rodriguez-Navarro, C., Jroundi, F., Schiro, M., RuizAgudo, E. \& González-Muñoz, M.T. 2012. Influence of substrate mineralogy on bacterial mineralization of calcium carbonate: Implications for stone conservation. Applied and Environmental Microbiology, 78(11): 4017-4029.

Rowshanbakht, K., Khamehchiyan, M., Sajedi, R.H. \& Nikudel, M.R. 2016. Effect of injected bacterial suspension volume and relative density on carbonate precipitation resulting from microbial treatment. Ecological Engineering, 89: 49-55.

Ruan, S., Qiu, J., Weng, Y., Yang, Y., Yang, E., Chu, J. \& Unluer, C. 2019. Cement and concrete research the use of microbial induced carbonate precipitation in healing cracks within reactive magnesia cement-based blends. Cement and Concrete Research, 115: 176-188.

Saad, A.H., Nahazanan, H., Yusoff, Z.M., Huat, B.K. \& Mustafa, M. 2018. Properties of biomineralization process in various types of soil and their limitations. International Journal of Engineering \& Technology, 7: 4973-4979.

Saneiyan, S., Ntarlagiannis, D. \& Colwell, F. 2021. Complex conductivity signatures of microbial induced calcite precipitation, field and laboratory scales. Geophysical Journal International, 224: 1811-1824.

Sarayu, K., Iyer, N.R. \& Murthy, A.R. 2014. Exploration on the biotechnological aspect of the ureolytic bacteria for the production of the cementitious materials - A review. Applied Biochemistry and Biotechnology, 172(5): 23082323

Schnell, S. \& King, G.M. 1996. Responses of methanotropic activity in soils and cultures to water stress. Applied and Environmental Microbiology, 62: 3203-3209

Seifan, M., Samani, A.K. \& Berenjian, A. 2016. Bioconcrete: next generation of self-healing concrete. Applied Microbiology and Biotechnology, 100(6): 2591-2602
Seifan, M. \& Berenjian, A. 2019. Microbially induced calcium carbonate precipitation: a widespread phenomenon in the biological world. Applied Microbiology and Biotechnology, 103: 46934708.

Shahrokhi-Shahraki, R., Zomorodian, S.M.A., O' Kelly, B.C. \& Niazi, A. 2015. Improving sand with microbial-induced carbonate precipitation. Proceedings of the Institution of Civil Engineers, 168(13): 217-230.

Siddique, R. \& Chahal, N.K. 2011. Effect of ureolytic bacteria on concrete properties. Construction and Building Materials, 25(10): 3791-3801.

Soon, N.W. 2013. Improvements in engineering properties of tropical residual soil by microbiallyinduced calcite precipitation (Ph.D). Universiti Tunku Abdul Rahman, Perak, Malaysia.

Srivastava, S., Bharti, R.K. \& Thakur, I.S. 2014. Characterization of bacteria isolated from palaeoproterozoic metasediments for sequestration of carbon dioxide and formation of calcium carbonate. Environmental Science and Pollution Research, 22(2): 1499-1511.

Sun, X. \& Miao, L. 2020. Application of bioremediation with Bacillus megaterium for crack repair at low temperature. Journal of Advanced Concrete Technology, 18: 307-319.

Tirkolaei, H.K. \& Bilsel, H. 2015. Statistical modeling of environmental factors on microbial urea hydrolysis process for biocement production. Advances in Materials Science and Engineering, 2015: 1-14.

Tobler, D.J., Cuthbert, M.O., Greswell, R.B., Riley, M.S., Renshaw, J.C., Handley-Sidhu, S. \& Phoenix, V.R. 2011. Comparison of rates of ureolysis between Sporosarcina pasteurii and an indigenous groundwater community under conditions required to precipitate large volumes of calcite. Geochimica et Cosmochimica Acta, 75(11): 3290-3301.

Uad, I., Gonzalez-Lopez, J., Silva-Castro, A.G., Vílchez, J.I., Gonzalez-Martinez, A., Martin-Ramos, D. \& Rivadeneyra, M.A. 2014. Precipitation of carbonates crystals by bacteria isolated from a submerged fixed-film bioreactor used for the treatment of urban wastewater. International Journal of Environmental Research, 8(2): 435446.

Umar, M., Kassim, K.A. \& Ping Chiet, K.T. 2016. Biological process of soil improvement in civil engineering: A review. Journal of Rock Mechanics and Geotechnical Engineering, 8(5): 767-774.

van Paassen, L., Daza, C., Staal, M., Sorokin, D., Zon, W. \& van Loosdrecht M. 2010. Potential soil reinforcement by biological denitrification. Ecological Engineering, 36: 168-175. 
Vijay, K., Murmu, M. \& Deo, S.V. 2017. Bacteria based self healing concrete $-\mathrm{A}$ review. Construction and Building Materials, 152: 1008-1014.

Warthmann, R., Lith, Y. Van \& Mckenzie, J.A. 2015. Bacterially induced dolomite precipitation in anoxic culture experiments. Geology, 28: 10911094.

Wath, R.B. \& Pusadkar, S.S. 2016. Soil improvement using microbial: A review. Indian Geotechnical Conference, 14: 329-335.

Wei, S., Fang, N., Cui, H., He, H., Jiang, Z. \& Hao, L. 2015. Biomineralization processes of calcite induced by bacteria isolated from marine sediments. Brazilian Journal of Microbiology, 46(2): 455-464.

Xu, J. \& Wang, X. 2018. Self-healing of concrete cracks by use of bacteria-containing low alkali cementitious material. Construction and Building Materials, 167: 1-14.

Xu, J., Du, Y., Jiang, Z. \& She, A. 2015. Effects of calcium source on biochemical properties of microbial $\mathrm{CaCO}_{3}$ precipitation. Frontiers in Microbiology, 6: 1-7.

Xu, J., Yao, W. \& Jiang, Z. 2014. Non-ureolytic bacterial carbonate precipitation as a sur face treatment strategy on cementitious materials. Journal of Materials in Civil Engineering, 26: 983-991.
Zamani, A. \& Montoya, B.M. 2019. Undrained cyclic response of silty sands improved by microbial induced calcium carbonate precipitation. Soil Dynamics and Earthquake Engineering, 120: 436-448.

Zhang, J., Zhao, C., Zhou, A., Yang, C., Zhao, L. \& $\mathrm{Li}, \mathrm{Z}$. 2019. Aragonite formation induced by open cultures of microbial consortia to heal cracks in concrete: Insights into healing mechanisms and crystal polymorphs. Construction and Building Materials, 224: 815-822.

Zhao, X., Wang, M., Wang, H., Tang, D., Huang, J. \& Sun, Y. 2019. Study on the remediation of $\mathrm{Cd}$ pollution by the biomineralization of ureaseproducing bacteria. International Journal of Environmental Research and Public Health, 16(2): 268-281.

Zhu, X., Kumari, D., Huang, M. \& Achal, V. 2016. Biosynthesis of CdS nanoparticles through microbial induced calcite precipitation. Materials and Design, 98: 209-214. 
